\title{
ANALISIS ORGANOLEPTIK MUTU HEDONIK DAN KIMIA BAKSO IKAN TUNA DENGAN PENAMBAHAN TEPUNG BUAH LINDUR (Bruguiera gymnorrhiza)
}

\author{
${ }^{1}$ Rahim Husain, ${ }^{1}$ Djainudin Djafar, ${ }^{*}$ Lis M. Yapanto \\ 1Jurusan Teknologi Hasil Perikanan Fakultas Perikanan dan Ilmu Kelautan \\ Unversitas Negeri Gorontalo. \\ 2Jurusan Sumber Daya Perairan Fakultas Perikanan Dan Kelautan \\ Universitas Negeri Gorontalo \\ Coresponding Authors: email :lizrossler@ung.ac.id
}

\begin{abstract}
This study aimstodeterminetheuseof lindur fruitflour (Bruguiera gymnorrhiza) in making tuna (Thunnussp) meat balls. And knowing the characteristics of the organoleptic quality and chemical quality of tuna (Thunnussp) meat balls with the addition of lindur fruit flour (Bruguiera gymnorrhiza). The treatment in this study was the addition of $20 \mathrm{gr}, 30$ grand $40 \mathrm{gr}$ lindur fruit flour to the tuna fish balls. The parameters tested were the organoleptic characteristics of hedonic quality whichh included appearance, aroma, taste and texture which were analyzed using Kruskall Walis. If there sults obtained have a significant effect, then proceed with the Duncan test to see the differences in the formulation treatments tested. Chemical characteristics (protein, fat, moisturecontent, ashandcarbohydrates) used a completely randomized design (CRD) and were analyzedby (ANOVA). The results of Duncan's continued test showed that the treatment of tuna meat ball formulations with the addition of different lindur fruit flour produced organoleptic characteristics of hedonic quality, appearance, aroma, taste and texture were significantly different. ANOVA test results show that the chemical characteristics of tuna fishballs are protein contentranging from 12.13-15.18\%, fat content from $3.73-4.52 \%$, moisture content $15.04-16.55 \%$, ash content 0.50 . $-0.55 \%$ and carbohydrates from 64.72 to $67.21 \%$.
\end{abstract}

Keywords: Meatballs, tuna fish, lindur fruitflour, Hedonic Quality Organoleptic, Chemical Quality

\begin{abstract}
ABSTRAK
Penelitian ini bertujuan untuk mengetahui pemanfaatan tepung buah lindur (Bruguiera gymnorrhiza) dalam pembuatan bakso ikan tuna (Thunnus sp). dan mengetahui karakteristik mutu organoleptik dan kimia bakso ikan tuna (Thunnus sp) dengan penambahan tepung buah lindur (Bruguiera gymnorrhiza). Perlakuan pada penelitian ini yaitu penambahan tepung buah lindur sebanyak 20 gr, 30 gr dan 40 gr pada bakso ikan tuna. Parameter yang di uji adalah karakteristik organoleptik mutu hedonik yang meliputi kenampakan, aroma, rasa dan tekstur yang dianalisis dengan menggunakan Kruskall Walis. Jika hasil yang diperoleh berpengaruh nyata maka dilanjutkan dengan uji Duncan untuk melihat perbedaan dari perlakuan formulasi yang diuji. Karaktristik kimia (protein, lemak, kadar air, kadar abu dan karbohidrat) menggunakan Rancangan Acak Lengkap (RAL) dan dianalisis dengan (ANOVA). Hasil uji lanjut Duncan menunjukkan bahwa perlakuan formulasi bakso ikan tuna dengan penambahan tepung buah lindur berbeda menghasilkan karakteristik organoleptik mutu hedonik kenampakan, aroma, rasa dan tekstur yang berbeda nyata. Hasil uji ANOVA menunjukkan bahwa karakteristik kimia bakso ikan tuna yaitu kadar protein berkisar 12,13-15,18\%, kadar lemak 3,73-4,52\%, kadar air 15,04-16,55\%, kadar abu 0,50-0,55\% dan karbohidrat 64,72-67,21\%.
\end{abstract}

Kata Kunci:Bakso, ikan tuna, tepung buah lindur, Organoleptik mutu hedonik, Mutu Kimia

Cara Mengutip (APA Citation Style)

Husain, R., Djafar, D., Yapanto L. M. 2021. Analisis Organoleptik Mutu Hedonik Dan Kimia Bakso Ikan Tuna Dengan Penambahan Tepung Buah Lindur (Bruguiera Gymnorrhiza). Jambura Journal of Animal Science, 3(2) 71-80 


\section{PENDAHULUAN}

Bruguiera gymnorrhiza Lindur adalah salah satu buah dari tanaman mangrove yang banyak ditemukan di wilayah perairan nusantara. Di Gorontalo, potensi tanaman lindur menyebar luas di wilayah perairan Teluk Tomini. Penelitian mengenai tepung buah lindur, hasilnya yaitu kadar air 11,63\%, kadar abu 1,40\%, kadar lemak 3,21\%, kadar protein 1,85\%, dan kadar karbohidrat 81,89\%. Keuntungan dari pemanfaatan tepung buah lindur sebagai bahan tambahan makanan dan dapat dimanfaatkan dan mengurangi impor biji gandum. Secara tidak langsung pemanfaatan buah lindur tersebut akan mengatasi ancaman rawan pangan bagi masyarakat serta mengatasi ancaman kerusakan lahan mangrove. Pemanfaatan tepung buah lindur tersebut dapat diaplikasikan pada bahan makanan, salah satunya yaitu bakso ikan.

Bakso ikan adalah produk olahan dari ikan yang dibuat dari lumatan daging ikan yang ditambahkan pati dan bumbubumbu serta direbus dalam air panas (Veranita, 2011). Selain rasanya yang enak, bakso umumnya sangat diminati hampir oleh seluruh kalangan. Berdasarkan (SNI:7266:2014-bakso ikan) salah satu syarat mutu bakso ikan adalah warnanya putih merata tanpa warna asing lain sehingga dalam pembuatan bakso ikan lebih banyak digunakan ikan berdaging putih.Bakso merupakan suatu produk gel dari protein hewani, baik sapi, ayam, ikan, dan udang. Bakso dibuat dari daging yang telah digiling dengan penambahan garam, tapioka, dan bumbu-bumbu, berbentuk bulat seperti kelereng dengan berat sekitar 25-30 g per butir dan diameter 2-7 cm atau sesuai dengan selera dan kebutuhan. Kualitas bakso sangat bervariasi tergantung dari bahan baku ikan dan bahan tambahan yang digunakan, proporsi daging dengan tepung, serta proses pembuatannya (Widyaningsih dan Murtini, 2006). Kriteria tersebut menggambarkan bahwa ikan tuna memiliki potensi untuk dimanfaatkan sebagai bahan baku pembuatan bakso
ikan.Tujuan penelitian untuk mengetahui analisis organoleptik mutu hedonik dan kimia bakso ikan tuna (Thunnussp.) dengan penambahan tepung buah lindur (Bruguiera gymnorrhiza).

\section{METODEPENELITIAN}

Penelitian telah dilaksanakan pada bulan April 2020-Mei 2020. Penelitian menggunakan metode eksperimen. Pengujian organoleptik dilakukan di Laboratorium Bioteknologi dan Hasil Perikanan Universitas Negeri Gorontalo, pengujian proksimat dilaksanakan di Pusat Penelitian Sumber daya Hayati dan Bioteknologi Lembaga Penelitian dan Pemberdayaan Masyarakat Institut Pertanian Bogor. Alat yang digunakan dalam pembuatan bakso yaitu termometer, blender, timbangan analitik dan perlengkapan lainnya. Alat uji organoleptik yaitu score sheet hedonik dan mutu hedonik SNI 01-2346-2006. Pengujian kadar protein metode Kjeldahl. Bahan yang digunakan ikan tuna, tepung buah mangrove jenis lindur (B. gymnorrhiza), dengan ukuran panjang 10-14 cm, diameter $1-2 \mathrm{~cm}$, berat rata-rata \pm 50 gram. Sampel yang telah dihaluskan, aquades, $\mathrm{H} 2 \mathrm{SO} 4$ pekat, $\mathrm{HgO}, \mathrm{H} 2 \mathrm{SO} 4, \mathrm{NaOH}, \mathrm{Na} 2 \mathrm{~S} 2 \mathrm{O} 3$, $\mathrm{H} 2 \mathrm{BO} 3$, indikator (campuran metil merah dan metilen biru), dan $\mathrm{HCl}$, petroleum eter.

Perlakuan dalam penelitian yaitu penambahan konsentrasi tepung buah lindur $20 \mathrm{~g}$, $30 \mathrm{~g}$ dan $40 \mathrm{~g}$ pada bakso ikan tuna yang kemudian dianalisis dengan menggunakan Anova. Jika hasil yang diperoleh berpengaruh nyata maka dilanjut dengan Duncan, untuk mengetahui perlakuan konsentrasi mana yang berbeda nyata.

\section{HASIL DAN PEMBAHASAN}

\section{A. Karakteristik Mutu Organoleptik Produk Bakso Ikan Tuna}

Uji organoleptik mutu hedonik merupakan faktor terpenting untuk mengetahui penerimaan panelis terhadap suatu produk baik makanan maupun minuman. Penilaian organoleptik mutu hedonik terhadap bakso ikan tuna meliputi kenampakan, aroma, rasa dan tekstur. 


\section{KenampakanBakso Ikan Tuna}

Histogram hasil analisis nilai organoleptik mutu hedonikkenampakan bakso ikan tuna dapat dilihat pada Gambar 1 .

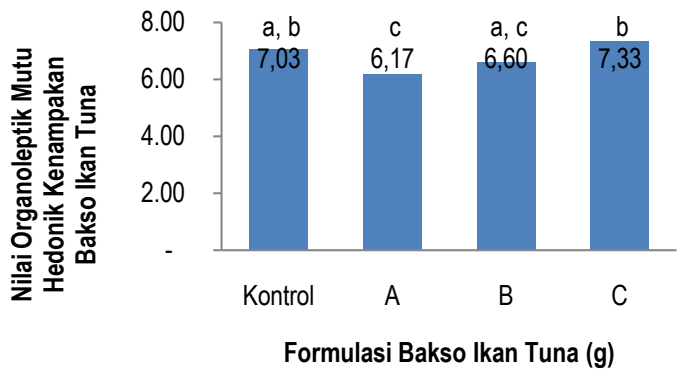

Gambar 1. Hasil uji organoleptik kenampakan bakso ikan tuna..

Keterangan:

$\mathrm{A}=$ Daging ikan tuna $100 \mathrm{~g}$ : Tepung lindur $40 \mathrm{~g}$ : Tepung tapioka $10 \mathrm{~g}$

$\mathrm{B}=$ Daging ikan tuna $100 \mathrm{~g}$ : Tepung lindur $30 \mathrm{~g}$ : Tepung tapioka $20 \mathrm{~g}$

$\mathrm{C}=$ Daging ikan tuna $100 \mathrm{~g}$ : Tepung lindur $20 \mathrm{~g}$ : Tepung tapioka $30 \mathrm{~g}$

Histogram Gambar 1 menunjukkan bahwa nilai organoleptik kenampakan bakso ikan tuna tertinggi adalah bakso hasil formulasi $C$ berada pada kriteria bentuk bulat beraturan, seragam, sedikit berongga, warna putih krem dengan nilai 7,33 dan nilai organoleptik kenampakan bakso terendah adalah hasil formulasi A berada pada kriteria bentuk bulat kurang beraturan, agak seragam, agak berongga, warna putih krem dengan nilai 6,17. Uji Kruskal-Wallis menunjukkan bahwa bakso ikan tuna dengan penambahan tepung buah lindur dan tepung tapioka menunjukan hasil yang berpengaruh nyata $(p<0,05)$ terhadap kenampakan bakso pada seluruh formulasi. Uji Duncan menunjukkan bahwa kenampakan bakso formulasi A berbeda tidak nyata dengan formulasi $\mathrm{B}$, sementara formulasi $\mathrm{B}$ dan $\mathrm{C}$ berbeda tidak nyata dengan kontrol serta formulasi $\mathrm{C}$ berbeda nyata dengan formulasi A dan $\mathrm{B}$.

Berdasarkan hasil penelitian bahwa kenampakan bakso ikan tuna formulasi C memiliki hasil penilaian karakteristik lebih tinggi dibandingkan formulasi A dan B. Kenampakan bakso ikan formulasi C dipengaruhi oleh jumlah perbandingan tepung buah lindur dan tepung tapioka yang ditambahkan yaitu (20 g : $30 \mathrm{~g})$. Hasil kenampakan bakso tersebut menunjukkan bahwa penggunaan tepung buah lindur dengan komposisi yang lebih banyak dibandingkan tepung tapioka akan menghasilkan kenampakan yang rendah, hal ini tentu ada kaitannya dengan warna tepung buah lindur dengan ciri krem sedikit kecoklatan, sedangkan pada tepung tapioka nampak sangat putih dan apabila dipanaskan (diolah) akan membentuk pasta amilopektin yang lebih cerah sehingga dapat meningkatkan mutu penampilan produk akhir.

Berdasarkan penelitian Husain (2016) bertambahnya konsentrasi substitusi tepung lindur pada formula kue kolombengi memberikan pengaruh pada warna karena pada tepung lindur memiliki warna alami yang dihasilkan dari kandungan tanin pada buah lindur. Selain itu dalam penelitian Dewidkk, (2014), dinyatakan bahwa penampilan kue kering putri salju dengan penambahan tepung lindur terlihat menarik karena warna coklat alami yang dihasilkan dari tepung buah lindur.

\section{Rasa Bakso Ikan Tuna}

Histogram hasil analisis nilai organoleptik mutu hedonik rasa bakso ikan tuna dapat dilihat pada Gambar 2. 


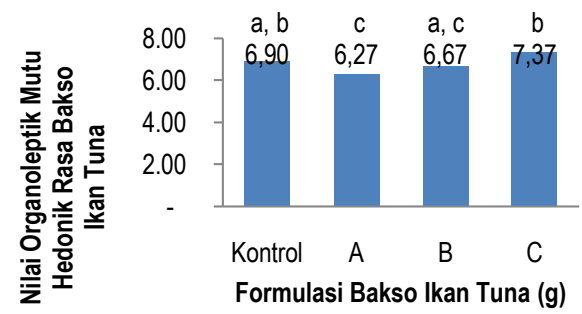

Gambar 2. Hasil uji organoleptik mutu rasa bakso ikan tuna.

Keterangan:

A = Daging ikan tuna $100 \mathrm{~g}$ : Tepung lindur $40 \mathrm{~g}$ : Tepung tapioka $10 \mathrm{~g}$

$\mathrm{B}=$ Daging ikan tuna $100 \mathrm{~g}$ : Tepung lindur $30 \mathrm{~g}$ : Tepung tapioka $20 \mathrm{~g}$

$\mathrm{C}=$ Daging ikan tuna $100 \mathrm{~g}$ : Tepung lindur $20 \mathrm{~g}$ : Tepung tapioka $30 \mathrm{~g}$

Histogram pada Gambar 2, tepung tapioka yang diberikan. Pada menunjukkan bahwa nilai organoleptik mutu hedonik rasa bakso ikan tuna tertinggi adalah bakso hasil formulasi C berada pada kriteria enak, rasa ikan sedikit berkurang dengan nilai 7,37 dan nilai organoleptik mutu rasa bakso terendah adalah hasil formulasi A berada pada kriteria Agak enak, rasa ikan kurang dengan nilai 6,27. Uji Kruskal-Wallis, menunjukkan bahwa bakso ikan tuna dengan penambahan tepung buah lindur dan tepung tapioka menunjukan hasil yang berpengaruh nyata $(p<0,05)$ terhadap rasa bakso. Uji Duncan menunjukkan bahwa rasa bakso formulasi A berbeda tidak nyata dengan formulasi $\mathrm{B}$, sementara formulasi $\mathrm{B}$ dan $C$ berbeda tidak nyata dengan kontrol serta formulasi $C$ berbeda nyata dengan formulasi A dan B.

Berdasarkan hasil penelitian rasa bakso ikan tuna formulasi $\mathrm{C}$ memiliki hasil penilaian yang lebih tinggi oleh panelis dibandingkan rasa bakso pada formula A dan B. Tingkat penerimaan panelis terhadap rasa bakso ikan tuna dari ketiga formulasi dibedakan berdasarkan jumlah formula C, rasa bakso ikan tuna yang dihasilkan memiliki nilai lebih tinggi sebab memiliki kriteria rasa khas ikan tuna, sedangkan penilaian pada formula A diduga disebabkan oleh tepung buah lindur dengan komposisi yang lebih banyak telah menutupi rasa dari bahan-bahan dalam formulasi dan sedikit agak sepat yang diduga karena getah yang terkandung dalam tepung buah lindur.

Berdasarkan penelitian terdahulu oleh Dewi $d k k$, (2014) bahwa kue kering putri salju dengan penambahan tepung buah lindur memenuhi kriteria rasa manis dan gurih, tetapi bila dibandingkan dengan kue putri salju dari tepung terigu, terasa manis dan sedikit terasa sepat dilidah. Setelah diolah menjadi tepung dan produk makanan rasa sepat masih sedikit terasa, walaupun tidak begitu dominan. Hal ini disebabkan karena buah lindur dalam keadaan segar mengandung getah dan tanin.

\section{Aroma Bakso Ikan Tuna}

Histogram hasil analisis nilai organoleptik mutu aroma bakso ikan tuna dapat dilihat pada Gambar 3. penambahan tepung buah lindur dan

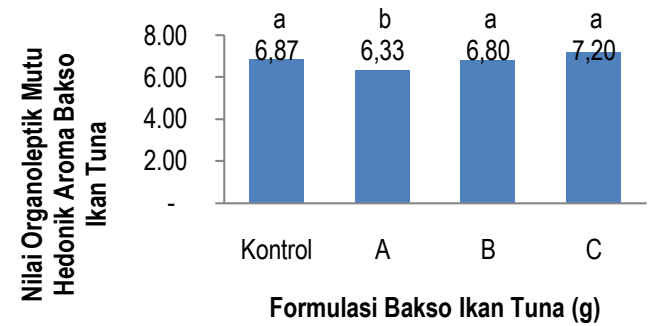

Keterangan:

A = Daging ikan tuna $100 \mathrm{~g}$ : Tepung lindur $40 \mathrm{~g}$ : Tepung tapioka $10 \mathrm{~g}$

$\mathrm{B}=$ Daging ikan tuna $100 \mathrm{~g}$ : Tepung lindur $30 \mathrm{~g}$ : Tepung tapioka $20 \mathrm{~g}$

$\mathrm{C}=$ Daging ikan tuna $100 \mathrm{~g}$ : Tepung lindur $20 \mathrm{~g}$ : Tepung tapioka $30 \mathrm{~g}$ 
Histogram pada Gambar 3, menunjukkan bahwa nilai organoleptik mutu aroma bakso ikan tuna tertinggi adalah hasil formulasi $C$ berada pada kriteria tidak amis, spesifik bakso ikan sedikit berkurang dengan nilai 7,20 dan nilai organoleptik mutu aroma bakso terendah adalah hasil formulasi A berada pada kriteria tidak amis, spesifik baso ikan berkurang dengan nilai 6,33. Uji KruskalWallis, menunjukkan bahwa bakso ikan tuna dengan penambahan tepung buah lindur dan tepung tapioka pada ketiga formulasi menunjukan hasil yang berpengaruh nyata $(p>0,05)$ terhadap aroma bakso yang dihasilkan. Hasil uji Duncan menunjukkan bahwa aroma bakso ikan tuna formulasi A berbeda nyata dengan seluruh formulasi lainnya.

Berdasarkan hasil penelitian, perlakuan formulasi bakso ikan tuna memberikan pengaruh yang nyata terhadap aroma yang dihasilkan karena diduga panelis tidak familiar dengan aroma bakso dengan jumlah komposisi tepung buah lindur lebih banyak, namun dikarena pada ketiga formulasi jumlah bahan daging ikan tuna yang digunakan lebih banyak dibandingkan bahan lain, maka aroma yang ditimbulkan masih memiliki ciri khas bakso ikan.

Hal tersebut sesuai dengan pendapat Winarno (1993) bahwa jenis ikan air tawar dan payau yang memiliki kandungan lemak rendah karakter bau dan rasanya tidak sejelas ikan laut yang memiliki kandungan protein dan lemak yang relatif lebih tinggi.

Hasrati dan Rusnawati (2011) menyatakan bahwa aroma daging ikan akan memberikan kesan bau amis pada bakso, karena kandungan protein dan urea dalam daging cukup tinggi. Aroma sangat menentukan tingkat penerimaan panelis dari suatu produk. Aroma yang enak atau khas akan meningkatkan selera konsumen.

\section{Tekstur Bakso Ikan Tuna}

Histogram hasil analisis nilai organoleptik mutu tekstur bakso ikan tuna dapat dilihat pada Gambar 4.

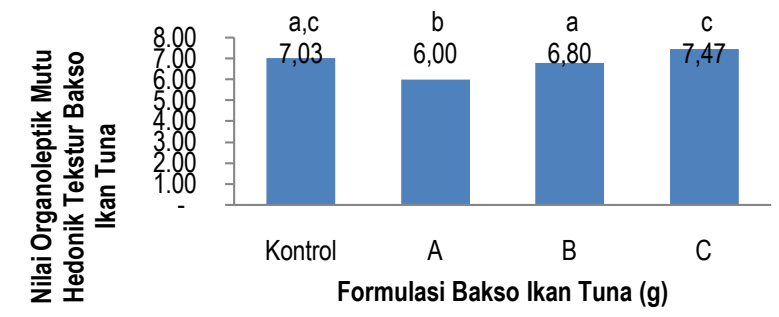

Gambar 4. Hasil uji organoleptik mutu hedonik tekstur bakso ikan tuna.

Keterangan:

$\mathrm{A}=$ Daging ikan tuna $100 \mathrm{~g}$ : Tepung lindur $40 \mathrm{~g}$ : Tepung tapioka $10 \mathrm{~g}$

$\mathrm{B}=$ Daging ikan tuna $100 \mathrm{~g}$ : Tepung lindur $30 \mathrm{~g}$ : Tepung tapioka $20 \mathrm{~g}$

$\mathrm{C}=$ Daging ikan tuna $100 \mathrm{~g}$ : Tepung lindur $20 \mathrm{~g}$ : Tepung tapioka $30 \mathrm{~g}$

Histogram pada Gambar 4, menunjukkan bahwa nilai organoleptik mutu tekstur bakso ikan tuna tertinggi adalah hasil formulasi C berada pada kriteria padat, kompak, agak kenyal dengan nilai 7,47 dan nilai organoleptik mutu tekstur bakso terendah adalah hasil formulasi A berada pada kriteria agak padat, agak kompak, agak kenyal dengan nilai 6,00. Uji Kruskal-Wallis menunjukkan bahwa bakso ikan tuna dengan penambahan tepung buah lindur dan tepung tapioka pada ketiga formulasi menunjukan hasil yang berpengaruh nyata $(p>0,05)$ terhadap tekstur bakso yang dihasilkan. Hasil uji Duncan menunjukkan bahwa tekstur bakso ikan tuna formulasi A berbeda nyata dengan seluruh formulasi lainnya, sedangkan formulasi B berbeda tidak nyata dengan formulasi kontrol, begitupula dengan formulasi $C$ menghasilkan tekstur yang berbeda tidak nyata dengan formulasi kontrol.

Tekstur bakso ikan tuna formulasi A dengan komposisi penambahan tepung buah lindur dan tapioka (40 g : $10 \mathrm{~g})$ menghasilkan nilai tekstur terendah karena memiliki ciri agak padat dan agak kenyal, hal tersebut tentu dipengaruhi oleh tepung buah lindur yang ditambahkan tidak cukup 
memberikan tingkat tekstur yang sesuai dengan bakso ikan pada umumnya. Adapun bakso dengan komposisi tepung tapioka lebih banyak seperti pada formulasi $\mathrm{C}$, penilaian panelis terhadap karakteristik tekstur yang dihasilkan justru paling bagik karena tingkat familiar panelis terhadap tekstur bakso tersebut. Selain itu jika ditinjau dari karakteristik tekstur bakso ikan dalam penelitian, tentu terdapat kandungan amilosa, amilopektin dan gluten pada tepung yang ditambahkan. Hal tersebut sejalan dengan penelitian terdahulu oleh Dewi $d k k$, (2014) menyataakan dalam penelitiannya bahwa penggunaan tepung lindur pada kue putri salju walaupun sudah melalui proses pangayakan, tekstur yang dihasilkan dari tepung buah lindur masih terasa lebih kasar jika dibandingkan dengan kue putri salju dari tepung terigu. Sedangkan Perkasa (2013) menambahkan bahwa penambahan tepung lindur akan mengurangi tingkat kerenyahan biskuit dan meningkatkan nilai kekerasan biskuit, hal ini disebabkan oleh proporsi tepung terigu yang banyak mengandung gluten akan berkurang jika ditambahkan tepung lindur. Hal tersebut dapat dijadikan acuan mengapa bakso formulasi A lebih memiliki karakteristik lebih rendah dari pada formulasi C, tentu karena dalam adonan bakso gluten pada tapioka terpengaruh dengan tepung buah lindur, sehingga kekenyalan menjadi berkurang sementara tingkat kepadatan menjadi meningkat.

\section{Karakteristik Kimiawi Produk Bakso Ikan Tuna}

Berikut bakso ikan tuna yang dianalisis meliputi protein, kadar air, lemak, kadar abu dan Karbohidrat.

\section{Kadar Protein Bakso Ikan Tuna}

Histogram rata-rata nilai kadar protein bakso ikan tuna dapat dilihat pada Gambar 5. menunjukkan bahwa kadar protein bakso ikan tuna bekisar 12,02-15,17\%.

Berdasarkan hasil analisis varians ANOVA, penambahan tepung buah lindur dan tepung tapioka dengan konsentrasi yang berbeda berpengaruh nyata $(p<0,05)$ terhadap kadar protein bakso

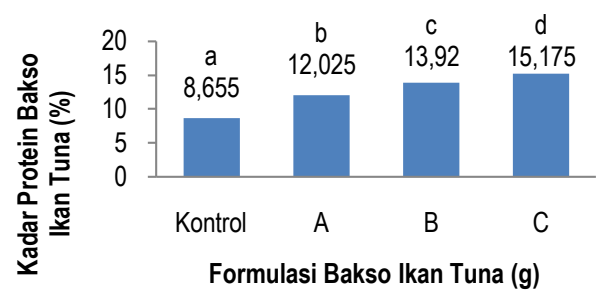

Gambar 5. Histogram kadar protein bakso ikan tuna.

Keterangan:

$\mathrm{A}=$ Daging ikan tuna $100 \mathrm{~g}$ : Tepung lindur $40 \mathrm{~g}$ : Tepung tapioka $10 \mathrm{~g}$

$\mathrm{B}=$ Daging ikan tuna $100 \mathrm{~g}$ : Tepung lindur $30 \mathrm{~g}$ : Tepung tapioka $20 \mathrm{~g}$

$\mathrm{C}=$ Daging ikan tuna $100 \mathrm{~g}$ : Tepung lindur $20 \mathrm{~g}$ : Tepung tapioka $30 \mathrm{~g}$

Hasil uji lanjut Duncan menunjukkan bahwa seluruh perlakuan formulasi menghasilkan jumlah kadar protein yang saling berbeda nyata.

Berdasarkan hasil penelitian, protein pada bakso dapat dipengaruhi oleh bahan dasar yaitu daging ikan tuna itu sendiri, tetapi dengan penambahan tepung buah lindur dan tepung tapioka pada setiap formulasi dalam jumlah yang berbeda ternyata menghasilkan kadar protein yang berbeda pula. Dalam penelitian ini, penggunaan daging ikan tuna pada semua formulasi jumlahnya sama, sedangkan yang membedakan yaitu adalah penggunaan tepung buah lindur dan tepung tapioka. Semakin sedikit jumlah tepung buah lindur yang diberikan dan semakin banyak tepung tapioka maka protein bakso ikan tuna semakin meningkat. Peningkatan protein tersebut diduga dipengaruhi oleh penurunan kadar air dalam bakso ikan tuna. Protein bakso juga dipengaruhi oleh bahan baku utama yaitu ikan tuna yang digunakan dalam proses pengolahannya. Walaupun penggunaan bahan baku ikan 
tuna pada seluruh perlakuan jumlahnya sama, namun protein yang terdeteksi pada perlakuan semakin meningkat. Menurut Perkasa (2013) menyatakan bahwa tepung yang dihasilkan dari buah lindur merupakan sumber bahan pangan nabati yang tinggi akan karbohidrat sekitar $81,89 \%$, sedangkan kandungan protein hanya sebesar 3,55\%. Hal tersebut menunjukkan bahwa berkurangnya komposisi penggunaan tepung buah lindur pada formulasi mempengaruhi peningkatan jumlah protein yang berasal dari daging ikan. Hal ini sesuai dengan pendapat Winarno (1991) bahwa pemakaian sejumlah kecil protein hewani dapat meningkatkan kadar protein nabati dalam jumlah yang besar.

\section{Kadar Karbohidrat Bakso Ikan Tuna}

Histogram rata-rata nilai kadar karbohidrat bakso dapat dilihat pada Gambar 6.

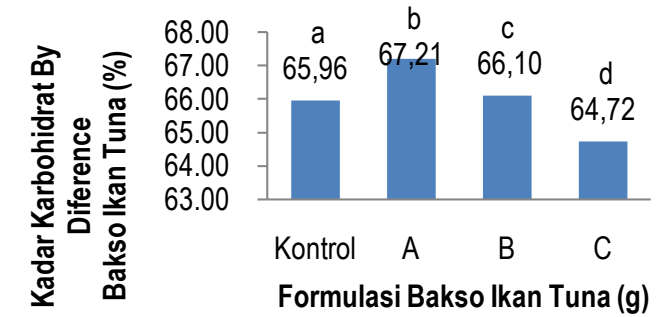

Keterangan:

Gambar 6. Histogram kadar karbohidrat bakso ikan tuna.

$\mathrm{A}=$ Daging ikan tuna $100 \mathrm{~g}:$ Tepung lindur $40 \mathrm{~g}:$ Tepung tapioka $10 \mathrm{~g}$

$\mathrm{B}=$ Daging ikan tuna $100 \mathrm{~g}$ : Tepung lindur $30 \mathrm{~g}$ : Tepung tapioka $20 \mathrm{~g}$

$\mathrm{C}=$ Daging ikan tuna $100 \mathrm{~g}$ : Tepung lindur $20 \mathrm{~g}$ : Tepung tapioka $30 \mathrm{~g}$

Histogram pada Gambar 7 pengolahan. Tingginya jumlah tepung buah menunjukkan bahwa kadar karbohidrat lindur yang ditambahkan pada formulasi, bakso ikan tuna bekisar 64,72 - 67,21\%. Berdasarkan hasil analisis varians ANOVA, penambahan tepung buah lindur dan tapioka dengan konsentrasi yang berbeda berpengaruh nyata $(p<0,05)$ terhadap kadar karbohidrat bakso. Hasil uji lanjut Duncan bahwa seluruh formulasi penambahan tepung buah lindur dan tapioka pada produk bakso ikan tuna menunjukkan hasil yang berbeda nyata $(\mathrm{p}<$ $0,05)$ terhadap kadar karbohidrat yang dihasilkan.

Berdasarkan hasil penelitian, menyebabkan jumlah karbohidrat yang terdeteksi pada bakso ikan tuna tinggi seperti pada formula A

Menurut Perkasa (2013) menyatakan bahwa tepung yang dihasilkan dari buah lindur merupakan sumber bahan pangan nabati yang tinggi akan karbohidrat sekitar $81,89 \%$. Hal tersebut menunjukkan bahwa komposisi tepung lindur yang ditambahkan dalam formulasi sangat mempengaruhi jumlah karbohidrat pada produk bakso yang dihasilkan.

\section{Kadar Air Bakso Ikan Tuna}

karbohidrat pada bakso ikan tuna Histogram rata-rata nilai kadar air dipengaruhi oleh jumlah penambahan bakso dapat dilihat pada Gambar 7 . tepung buah lindur pada perlakuan saat

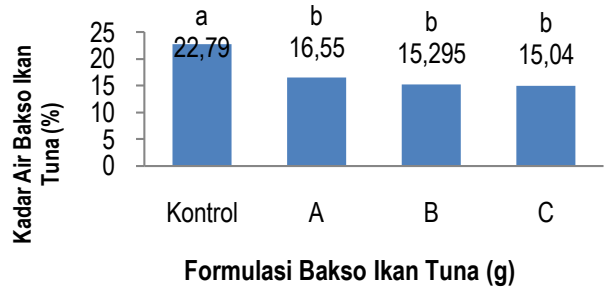

Gambar 7. Histogram kadar air bakso ikan tuna.

Keterangan

$\mathrm{A}=$ Daging ikan tuna $100 \mathrm{~g}$ : Tepung lindur $40 \mathrm{~g}$ : Tepung tapioka $10 \mathrm{~g}$

$\mathrm{B}=$ Daging ikan tuna $100 \mathrm{~g}$ : Tepung lindur $30 \mathrm{~g}$ : Tepung tapioka $20 \mathrm{~g}$

$\mathrm{C}=$ Daging ikan tuna $100 \mathrm{~g}$ : Tepung lindur $20 \mathrm{~g}$ : Tepung tapioka $30 \mathrm{~g}$ 
Histogram pada Gambar 8 menunjukkan bahwa kadar air bakso ikan tuna bekisar 15,04 - 16,55\%. Berdasarkan hasil analisis varians ANOVA, penambahan tepung buah lindur dan tepung tapioka dengan konsentrasi yang berbeda berpengaruh nyata $(\mathrm{p}<0,05)$ terhadap kadar air bakso. Uji lanjut duncan menunjukkan bahwa perlakuan formulasi A, B dan C tidak berbeda nyata, namun berbeda nyata dengan perlakuan kontrol terhadap kadar air bakso ikan tuna.

Berdasarkan hasil penelitian, kadar air bakso ikan tuna dipengaruhi oleh jumlah tepung buah lindur yang ditambahkan. Semakin sedikit jumlah penambahan tepung buah lindur dan semakin banyak tepung tapioka, maka kadar air semakin rendah. Hal tersebut menunjukkan bahwa tepung buah lindur masih memiliki keamampuan yang jauh lebih rendah dibandingkan tepung tapioka. Tepung mengandung granula-granula pati yang dapat mengikat air dan dengan bantuan panas maka akan berubah menjadi gel, sehingga ketika ditambahkan dalam jumlah yang lebih banyak pada adonan dapat menyebabkan penurunan kadar air bakso ikan. Selain itu, kadar air juga dipengaruhi oleh kadar lemak dalam produk bakso, jika kadar lemak semakin tinggi maka kadar air semakin rendah, namun sebaliknya jika kadar lemak semakin rendah maka kadar air semakin tinggi. Rendahnya kadar air bakso ikan tuna juga ditandai dengan tingkat kekenyalan dan tekstur pada produk tersebut.

Selama perubahan ini granula pati mengembang pada tingkat tertentu dan menyebar melewati struktur jala protein ikan. Mengembangnya granula pati tersebut menyebabkan tekanan yang kuat pada matriks protein disertai dengan penarikan air yang berada di sekitar matriks protein sehingga menghasilkan gel yang lebih kuat dan kohesif.

\section{Kadar Lemak Bakso Ikan Tuna}

Histogram rata-rata nilai kadar lemak bakso dapat dilihat pada Gambar 8 .

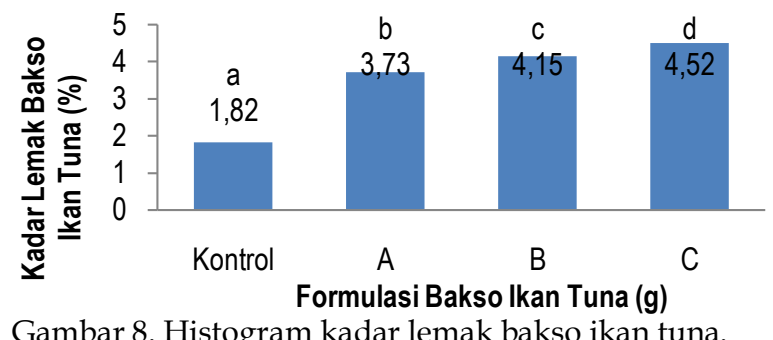

Keterangan:

$\mathrm{A}=$ Daging ikan tuna $100 \mathrm{~g}$ : Tepung lindur $40 \mathrm{~g}$ : Tepung tapioka $10 \mathrm{~g}$

$\mathrm{B}=$ Daging ikan tuna $100 \mathrm{~g}$ : Tepung lindur $30 \mathrm{~g}$ : Tepung tapioka $20 \mathrm{~g}$

$\mathrm{C}=$ Daging ikan tuna $100 \mathrm{~g}$ : Tepung lindur $20 \mathrm{~g}$ : Tepung tapioka $30 \mathrm{~g}$

Histogram pada Gambar 8 menunjukkan bahwa kadar lemak bakso ikan tuna bekisar 3,72-4,51\%. Berdasarkan hasil analisis varians ANOVA, penambahan tepung buah lindur dan tapioka dengan konsentrasi yang berbeda berpengaruh nyata $(\mathrm{p}<0,05)$ terhadap kadar lemak bakso. Hasil uji duncan menunjukkan bahwa seluruh perlakuan formulasi berbeda nyata $(p>0,05)$ terhadap kadar lemak bakso ikan tuna.

Berdasarkan hasil penelitian, kadar lemak bakso ikan tuna dipengaruhi oleh bahan yang ditambahkan dalam adonan seperti daging ikan itu sendiri, walaupun daging ikan yang ditambahkan pada seluruh formulasi dalam jumlah yang sama, tepung buah lindur serta tepung tapioka. Tepung buah lindur mengandung sekitar $0,23 \%$ lemak, sementara ikan tuna mengandung sekitar 2,7\%, dengan kandungan lemak tersebut maka mengakibatkan peningkatan kadar lemak pada bakso ikan tuna. Selain itu kadar lemak pada ketiga formulasi berhubungan dengan kandungan air dalam bahan adonan bakso. Semakin rendah kadar air pada 
formulasi, maka menyebabkan kandungan lemak semakin tinggi.

\section{Kadar Abu Bakso Ikan Tuna}

Histogram rata-rata nilai kadar abu bakso dapat dilihat pada Gambar 9.

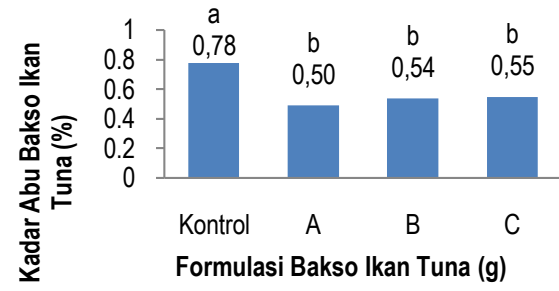

Gambar 9. Histogram kadar abu bakso ikan tuna.

Keterangan

A = Daging ikan tuna $100 \mathrm{~g}$ : Tepung lindur $40 \mathrm{~g}$ : Tepung tapioka $10 \mathrm{~g}$

$\mathrm{B}=$ Daging ikan tuna $100 \mathrm{~g}$ : Tepung lindur $30 \mathrm{~g}$ : Tepung tapioka $20 \mathrm{~g}$

$\mathrm{C}=$ Daging ikan tuna $100 \mathrm{~g}$ : Tepung lindur $20 \mathrm{~g}$ : Tepung tapioka $30 \mathrm{~g}$

Histogram pada Gambar 9 menunjukkan bahwa kadar abu bakso ikan tuna bekisar 0,50-0,55\%. Berdasarkan hasil analisis varians ANOVA, penambahan tepung buah lindur dan tepung tapioka dengan konsentrasi yang berbeda berpengaruh nyata $(p<0,05)$ terhadap kadar abu bakso. Hasil uji duncan menunjukkan bahwa formulasi A, B dan C berbeda tidak nyata namun ketiga formulasi tersebut berbeda nyata dengan formulasi kontrol.

Hasil penelitian menunjukkan bahwa, penambahan tepung buah lindur dengan jumlah yang lebih banyak menyebabkan kandungan abu pada produk bakso ikan tuna justru lebih sedikit dibandingkan dengan penambahan tepung tapioka dengan komposisi lebih banyak. Menurut Perkasa (2013) tepung lindur memiliki kadar abu yang lebih besar dibandingkan dengan tepung terigu, namun lebih sedikit dibandingkan kadar abu tepung tapioka. Kadar abu yang dianalisis pada penelitian ini adalah kadar abu total, dimana kadar abu masih merupakan campuran dari komponen anorganik atau mineral yang terdapat dalam suatu bahan pangan. Selain itu kadar abu bakso ikan tuna dapat berasal dari bahan-bahan yang ditambahkan seperti

\section{DAFTAR PUSTAKA}

Dewi Putu D.P, Wayan N. Sukerti dan Ekayani I. Ayu Putu Hemy. 2014. Pemanfaatan Tepung Buah Mangrove Jenis Lindur (Bruguiera gymnorrizha) Menjadi Kue Kering Putri Salju. daging ikan tuna. Namun kandungan abu pada produk bakso ikan tuna yang terdeteksi masih memenuhi syarat mutu bakso ikan berdasarkan SNI yaitu maksimal 2\% (BSN, 2014). menambahkan bahwa rendahnya kadar abu pada suatu produk menunjukkan kecilnya jumlah mineralmineral yang terkandung dalam produk tersebut. Sebagian besar bahan makanan yaitu sekitar 90\% terdiri dari bahan organik dan air. Sisanya terdiri atas unsur mineral (zat organik). Pada proses pembakaran, bahan organik terbakar tetapi zat organiknya tidak terbakar, oleh karena itu disebut abu.

\section{KESIMPULAN}

Karakteristik mutu hedonik terbaik untuk bakso ikan tuna yang di tambahkan tepung buah lindur yaitu pada formulasi penambahan tepung lindur $20 \mathrm{~g}$. Kenampakan karateristik berbentuk bulat beraturan, seragam, sedikit berongga, warna putih krem, tekstur padat, kompak, agak kenyal, aroma tidak amis, spesifik rasa gurih, rasa ikan sedikit berkurang. Mutu kimia bakso memenuhi syarat mutu berdasarkan SNI bakso ikan yang baik.

Jurusan Pendidikan Kesejahteraan Keluarga, FTK Universitas Pendidikan Ganesha.

Hasrati, E. dan Rusnawati, R. 2011. Kajian penggunaan daging ikan mas (Cyprinus CarpioLinn) terhadap 
tekstur dan cita rasa bakso daging sapi. Jurnal Agromedia Vol. 29, No. 1.

Lamanta, I. L. (2020). Pemanfaatan Akar Eceng Gondok (Eocornia Crassipes) Sebagai Bahan Pengawet Telur Ayam Ras. Jambura Journal of Animal Science, 3(1), 46-53.

Katili, A S. 2009. Struktur Vegetasi Mangrove Di Kecamatan Kwandang Kabupaten Gorontalo Utara. Jurnal Pelangi Ilmu Vol. 2: 19.

Perkasa, Hardi. 2013. Pemanfaatan Tepung Buah Lindur (Bruguiera gymnorrhiza) Dalam Pembuatan Biskuit. Skripsi. Institut Pertanian Bogor. Bogor

Husain, R., Yapanto, L. M., \&Pasilia, G. J. (2021). AnalysisofOrganolepticand Chemical Qualityof Dodol Ketan withtheAdditionofCarabanx LeptolepisFlo ur. 25(3), 2927-2937.
Suzuki T. 1981 Fishand Krill Protein Processing Tecnology. Applied Science Publiching. Ltd. London

Veranita, D. 2011. Strategi Pengembangan Usaha Bakso Ikan Tuna Surimi dan Campuran (Studi Kasus pada CV. Bening Jati Anugerah, Bogor). Tesis. Sekolah Pascasarjana. Institut Pertanian Bogor. Bogor.

Widyaningsih, T.D. \& E.S. Murtini. 2006. Alternatif pengganti formalin pada pangan. Cetakan I. Trubus Agrisarana. Surabaya.

Winarno, F. G., 1992. Keamanan Pangan. Naskah Akademis. Bogor. 515 hal.

Yapanto, L. M. (2020). Tataniaga Dan Margin Pemasaran Ikan Tuna Di Kota GorontALO. Jambura Journal of Animal Science, 2(2), 38-45. 